\title{
Mineral Content of Minor Fruits of South Gujarat, India
}

\author{
B. Abuj Bhagyashree ${ }^{1 *}$, Nilima Karmakar ${ }^{1}$, V. Rathwa Kalpana ${ }^{2}$, \\ Kapadiya Chintan ${ }^{3}$ and V. Narwade Ajay \\ ${ }^{1}$ Department of Soil Science and Agricultural Chemistry, Navsari Agricultural University, \\ Gujarat, India \\ ${ }^{2}$ Department Genetics and Plant Breeding, N. M. College of Agriculture, Navsari, \\ Gujarat -396450, India \\ ${ }^{3}$ Department of Plant Molecular Biology and Biotechnology ASPEE College of Horticulture and \\ Forestry N. A. U., Navsari, Gujarat, India \\ *Corresponding author
}

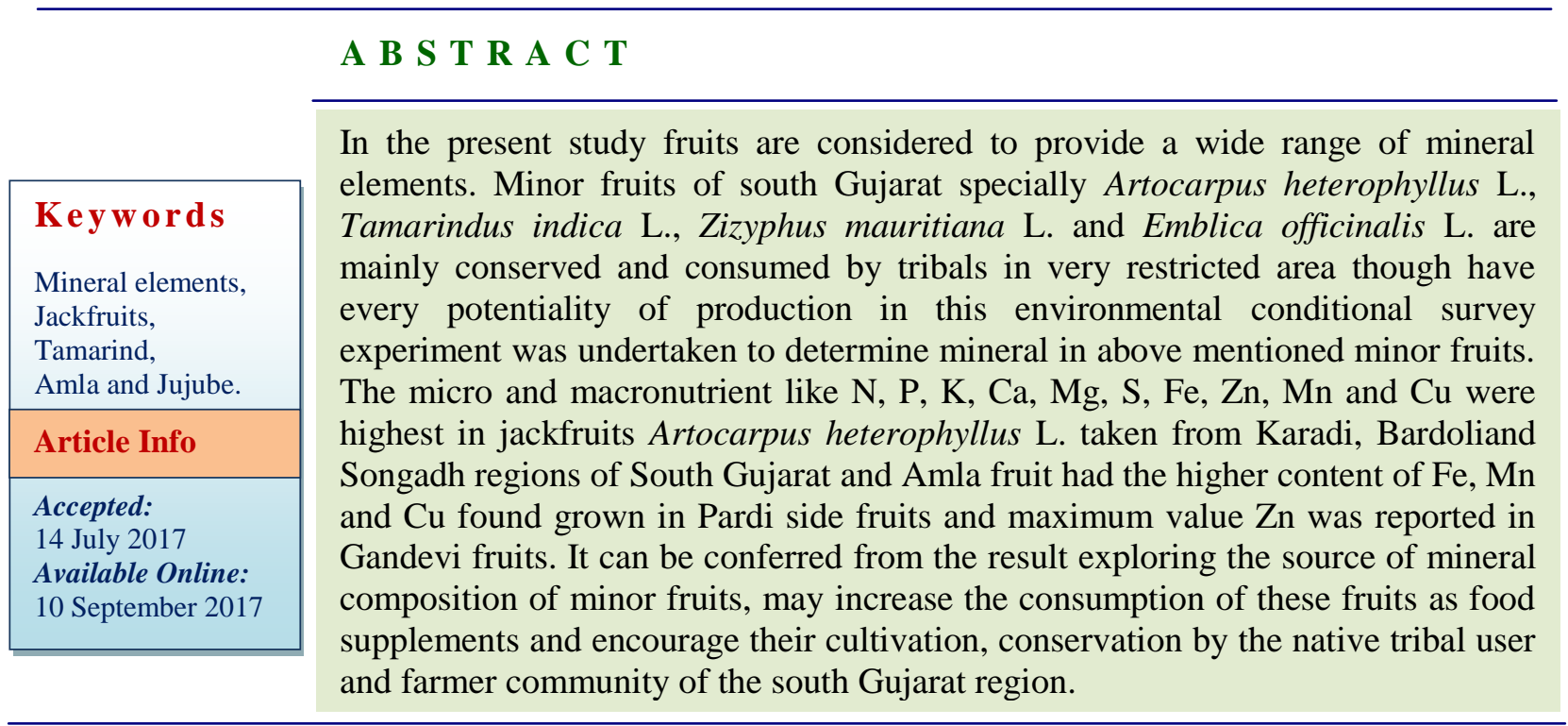

\section{Introduction}

In a general sense, those fruits which though are consumable to the human being but relatively less palatable than other fruits, which have lesser demand in the market, which are grown to a limited extent only and are not usually cropped in organized plantations with application of inputs are considered in grouping as minor fruit crops. Other terms that are used for minor fruits are less-known fruits, less appealing fruits, less exploited fruits, stray fruits, wild fruits (Mazumdar, 2004). More than 30\% of rural families in India are living in poverty due to small holding size and low soil productivity (Hegde, 2009). As many underutilized tree species are tolerant to harsh agro-climatic conditions, Bharatiya Agro Industries Foundation has promoted agri-horti-forestry using these tree species on degraded hilly terrains in the Western Ghats region of 
Gujarat and Maharashtra. The tribal inhabitants of this region, traditionally dependent on non-timber forest products, preferred local fruit species instead of arable food crops, and selected Jackfruit (Artocarpus heterophyllus L.), Tamarind (Tamarindus indica L.), Ber (Zizyphus mauritiana L.) and Amla (Emblica officinalis L.) (Hegde, 2009). Many of these underutilized species, survived under harsh agroclimatic conditions, can be established on degraded lands, which are presently being underutilized either due to poor soil fertility or moisture scarcity. However, most of these species are in a state of neglect, while a small number of them are under cultivation in their native tracts by local communities for specific household uses only.

The jackfruit (Artocarpus heterophyllus L.) belongs to family Moraceae and genus Artocarpus. It is the largest tree born fruit in the world. The genus Artocarpus contains about 50 species; most are native to Asia. Jackfruit is rich in several nutrients. It can act as source of complete nutrition to the consumers.

It is rich in vitamin $\mathrm{B}$ and $\mathrm{C}$, potassium, calcium, iron, proteins and high level of carbohydrates, jackfruit affordable and readily available supplement to our staple food Priya et al., (2014). The nutritional aspects of various edible fruit parts of jackfruit (Artocarpus heterophyllus). Jackfruit contains higher content of calcium, magnesium, copper, iron, as per the finding of Tiwari and Vidyarthi (2015).

Tamarind (Tamarindus indica L.) belongs to the family Fabaceae subfamily Caesalpiniodeae, tribe Amherstieae and Genus Tamarindus (Leonard, 1957). Tamarind is a well-known for its nutrition and various uses. The properties of this species have been extensively studied. Tamarind has many valuable properties and virtually every part of the tree has been utilized by both rural and urban dwellers. The most valuable and commonly used part of the tamarind tree is the fruit. Tamarind pulp is also rich in minerals like potassium, phosphorous, iron, sodium, zinc and calcium according to Parvez et al., (2003).

Indian jujube (Ziziphus jujube L.) is also known as ber, jujube, desert apple or Indian plum. It belongs to the genus Ziziphus and family Rhamnaceae. It is called the king of arid zone fruits. Ber is the Urdu name for the fruit of the tree Zizyphus vulgaris, or mauritaniaor sativa and is called the jujube berry in English. It is also known as the Indian jujube or Chinese date.

The ber fruit has high sugar content and a high level of vitamins A \& $\mathrm{C}$, carotene, phosphorus, pospherous, magannis, iron and calcium. Ber can provide food security, due to sustained production of the fruits, irrespective of drought and salinity; it grows well on poor and degraded land.

Indian gooseberry (amla) is one of the most important plants of Ayurveda. It is small to medium deciduous tree belonging to a family Euphorbiaceae growing in India, Sri Lanka, Pakistan, Uzbekistan, South East Asia, and China. In Sanskrit, Emblicahas many synonyms: Amalaki (pure, clean), Dhatriphala (nurse fruit), Amritaphala (fruit of immortality), Amla, Anola, Emblica, Gooseberry and others. All of these synonyms show how important this plant is in traditional Indian medicine. The fruits of Emblicaare widely consumed as raw, cooked or pickled. They are also principal constituents of many Ayurvedic preparations (Scartezzini and Speroni 2000; Khatoon et al., 2006). Amla is well known for its nutritional qualities. It is one of the most extensively studied plants due to its richness in polyphenols, minerals and is regarded as one of the richest source of 
vitamin C (Jain et al., 2000; Bharthakur et al., 1991). The amla fruit are rich in mineral contents such as Calcuium, phospherous, iron,copper, magnnis, magnessium, cobolt reported by Poonam and Mahanta (2014).

\section{Materials and Methods}

The present study was conducted at the Department of Soil Science and Agricultural Chemistry, N. M. College of Agricultural, Navsari Agricultural University, Navsari. The fresh fruit samples of Jackfruit, Tamarind, Indian jujube and Amla for experiment collected from local cultivar of South Gujarat includes the districts of Navsari, Surat, Bharuch, Valsad, Tapi, Narmada and Dang (Table 1).

\section{Sampling material}

Fresh and dry powdered fruit.

\section{Time of harvesting}

Edible maturity stage.

\section{Sample preparation}

Fresh fruits at edible maturity stage were harvested from different plants and were subjected to different types of chemical analysis.

\section{Total nitrogen}

The total nitrogen content was determined by the method of Kjeldhal method (Jackson, 1979).

Determination of total $\mathrm{P}, \mathrm{K}, \mathrm{S}$, Ca and $\mathrm{Mg}$ elements from fruits samples by wet digestion method

This procedure was preferred to dry ignition, because of possibility of loss of mineral constituents at high temperature during dry ignition. $0.5 \mathrm{gm}$ dried fruits powder was taken in $150 \mathrm{ml}$ conical flask. $10-15 \mathrm{ml}$ of di-acid $\left(\mathrm{HNO}_{3}: \mathrm{HClO}_{4}=10: 4\right)$ mixture was added and a funnel was placed on the flask and allowed to stand for overnight. The mixture was heated gently at first on hot plate, and then heated more vigorously until a clear solution was obtained. The mixture was not heated to dryness as phosphorus and arsenic might be lost if the solution was dried. Heating was continued till the volume reduced to approximately 3 to $5 \mathrm{ml}$. After that the clear solution was cooled and transferred to a $100 \mathrm{ml}$ volumetric flask through filter paper Whatman No.01 and the volume was made up to the mark This solution was stored and used for further analysis of $\mathrm{P}, \mathrm{K}, \mathrm{S}, \mathrm{Ca}$ and $\mathrm{Mg}$ elements.

\section{Determination of phosphorus}

Determination of phosphorus from fruits sample was done by using spectrophotometer by Jackson, (1967) method.

\section{Determination of potassium}

Determination of Potash from fruits sample was done using flame photometer by the method of Jackson (1967).

\section{Determination of sulphur}

Determination of sulphur from fruits sample was done using turbid metric spectrophotometer by Tandon (1993) method.

\section{Determination of $\mathrm{Ca}$ and $\mathrm{Mg}$}

The fruits sample using Versanate (EDTA) titration by Cheng and Bray (1951) method.

\section{Determination of micronutrient using atomic absorption}

\section{Spectrophotometric method}

Micronutrients $(\mathrm{Fe}, \mathrm{Mn}, \mathrm{Cu}$, and $\mathrm{Zn})$ were estimated by the method of Elwell and Gridley, (1967). 


\section{Results and Discussion}

\section{Mineral elements of jackfruit}

The mineral content of jackfruit in different locations of South Gujarat was differed significantly (Table 2). The highest value of nitrogen content $(184.53 \mathrm{mg} / 100 \mathrm{gm})$ was obtained in Navsari grown fruits compared to the rest of the other places respectively. The nitrogen content in above finding is agreed with results of Goswami et al., (2011). They reported nitrogen content in jackfruits varied from $137 \mathrm{mg} / 100 \mathrm{gm}$ to $191 \mathrm{mg} / 100 \mathrm{gm}$.

The maximum content of phosphorous reported in Valsad fruits $(411.50 \mathrm{mg} / 100 \mathrm{gm})$ which is at par with Bardoli fruits (409.30 $\mathrm{mg} / 100 \mathrm{gm}$ ) respectively. Thus the present finding was more or less similar with the finding of Narasimham (1990). He reported amount of $\mathrm{P}$ content in jackfruits ranged from $380 \mathrm{mg} / 100 \mathrm{gm}$ to $400 \mathrm{mg} / 100 \mathrm{gm}$.

The higher potassium content was reported in Valsad fruits $(338.67 \mathrm{mg} / 100 \mathrm{gm})$ which is at par with Songadh fruits $(337.00 \mathrm{mg} / 100 \mathrm{gm})$. The potassium content of present table found similar ranged (191 to $407 \mathrm{mg} / 100 \mathrm{gm}$ ) with this study reported by Narasimham (1990).

Significantly higher content was found in Bardoli fruits $(36.09 \mathrm{mg} / 100 \mathrm{gm})$. The value of calcium is comparable with results of Gunasena et al., (1996).They reported Calcium content in jackfruit ranged from 20 $\mathrm{mg} / 100 \mathrm{gm}$ to $37 \mathrm{mg} / 100 \mathrm{gm}$ respectively. There was no significant difference observed in it. The maximum value of Magnesium content was reported in Bardoli side fruits (32.88mg /100gm) followed by Songadh fruits $(32.35 \mathrm{mg} / 100 \mathrm{gm})$. The present finding was more or less similar with those reported by Narasimham (1990). Maximum sulfur content recorded in Songadh $64.33 \mathrm{mg} / 100 \mathrm{gm}$ while minimum sulfur content in Navsari $61 \mathrm{mg} / 100 \mathrm{gm}$ respectively. The maximum iron content was recorded in the Hasapur grown fruits $(2.04 \mathrm{mg} / 100 \mathrm{gm})$ followed by Karadi fruits $(1.88 \mathrm{mg} / 100 \mathrm{gm})$. The result of above finding was similar with that reported of that by Gunasena et al., (1996). They found Fe content in jackfruit was about 0.5 to 1.1 $\mathrm{mg} / 100 \mathrm{gm}$ respectively.

Zinc content in jackfruit pulp ranged from 0.09 to $0.11 \mathrm{mg} / 100 \mathrm{gm}$. The highest zinc content observed in Navsari fruits $(0.11 \mathrm{mg} / 100 \mathrm{gm})$. The range of zinc content in jackfruit varied from $(0.07-0.13 \mathrm{mg} / 100 \mathrm{gm})$ reported by Ragone and Cavaletto (2006).

There was no significant difference observed in it. The maximum value of manganese was reported in Bardoli side fruits $(0.57 \mathrm{mg}$ /100gm). Tiwari and Vidyarthi (2015) reported range of manganese content varied from 54 to $60 \mathrm{mg} / 100 \mathrm{gm}$ in different age of fruits maturity which is more or less similar with above results respectively. Higher copper content was observed in Bardoli fruits $(0.84 \mathrm{gm} / 100 \mathrm{gm})$ followed by Songadh grown fruits $(0.81 \mathrm{gm} / 100 \mathrm{gm})$. Parvez et al., (2003) reported similar copper content in jackfruit was approximately $0.8 \mathrm{mg} / 100 \mathrm{gm}$ respectively.

\section{Mineral elements of tamarind}

The perusal of data presented in table 3 reported significant variation in mineral element content in tamarind fruits collected from various location of South Gujarat. Highest $\mathrm{N}$ content was found in Navsari location fruits $(82.24 \mathrm{mg} / 100 \mathrm{gm})$. The present results were found to be closer to the findings of Wenkam and Miller (1965). They reported the nitrogen content in tamarind was about $59 \mathrm{mg} / 100 \mathrm{gm}$.

The results showed the highest phosphorous content in Pardi grown fruits (6.18 $\mathrm{mg} / 100 \mathrm{gm})$ which was at par with Valsad fruits $(6.16 \mathrm{mg} / 100 \mathrm{gm})$, Navsari fruits $(6.09$ 
$\mathrm{mg} / 100 \mathrm{gm}$. The higher value of phosphorous content than above finding was reported by Parvez et al., (2003). They obtained phosphorous content in tamarind pulp varied from $62-570 \mathrm{mg} / 100 \mathrm{gm}$.

Higher content of potassium was found in Dang fruits and (34 mg/100gm) while the lower value was in recorded in Chikhli fruits (30 mg/100gm).

Anon (1976) and Duke (1981) reported the potassium content are similar to present work. They reported K content ranged from 30 to 40 $\mathrm{mg} / 100 \mathrm{gm}$.

The maximum calcium content was observed in Chikhli fruits $(90.67 \mathrm{mg} / 100 \mathrm{gm})$. The range of calcium content in varied from $81.67 \mathrm{mg} / 100 \mathrm{gm}$ to $90.67 \mathrm{mg} / 100 \mathrm{gm}$.The calcium content in tamarind fruits ranged from 34 to $94 \mathrm{mg} / 100 \mathrm{gm}$ reported by Coronel (1991). Higher 72mg/100gm content was observed in Dang region fruits $(87.67 \mathrm{mg} / 100 \mathrm{gm})$ which is at par with fruits of Pardi $(87.33 \mathrm{mg} / 100 \mathrm{gm})$ and Chikhli $(85.67 \mathrm{mg} / 100 \mathrm{gm})$. The $\mathrm{Mg}$ content in tamarind pulp ranged between $(80.67$ to $87.67 \mathrm{mg} / 100 \mathrm{gm}$ ) respectively.

The higher sulfur content was observed in Dharampur fruits (149.66 mg /100gm). The range of sulfur content in tamarind from 141.66 to $149.66 \mathrm{mg} / 100 \mathrm{gm}$. Parvez et al., in 2003 reported the sulfur content in tamarind fruits varied from 102 to $150 \mathrm{mg} / 100 \mathrm{gm}$ respectively. However, numerically higher value of iron content was observed in Navsari grown fruits $0.96 \mathrm{mg} / 100 \mathrm{gm}$. Coronel (1991) found similar result of above finding. They reported iron content in tamarind ranged from 0.2 to $0.9 \mathrm{mg} / 100 \mathrm{gm}$ respectively. However, numerically higher value of zinc content was observed in Navsari grown fruits 0.12 mg/100gm respectively. Parvez et al., (2003) reported Zinc content in tamarind varied from $0.8-0.9 \mathrm{mg} / 100 \mathrm{~g}$ respectively.

Highest manganese content was observed in the tamarind fruits of Navsari (2.80mg/100gm). Parvez et al., (2003) found similar results as like above findings. They recorded $\mathrm{Mn}$ content in tamarind ranged from 2.56- $3.02 \mathrm{mg} / 100 \mathrm{gm}$.

The highest value of copper content $(0.103$ $\mathrm{mg} / \mathrm{gm}$ ) was obtained in Navsari grown fruits compared to the rest of the other places of south Gujarat. The results of above finding agree with result of Parvez et al., (2003). They observed copper content in tamarind ranged from $0.8-1.2 \mathrm{mg} / 100 \mathrm{gm}$.

\section{Mineral elements of Indian jujube}

The perusal of data presented in table 4 . Revealed that the jujube collected from different places of South Gujarat significantly differed in respect of mineral content. The nitrogen content in jujube collected ranged from $144.33 \mathrm{mg} / 100 \mathrm{gm}$ to $163.33 \mathrm{mg}$ / $100 \mathrm{gm}$. The maximum content of nitrogen was found in the fruits of Vyara and Dungri $(163.33 \mathrm{mg} / 100 \mathrm{gm})$ which is at par with the fruits obtained from Aat (159.67mg/ 100gm).

Table.1 Fruits sample collected from different following places

\begin{tabular}{|l|l|l|l|l|l|l|}
\hline Fruits & \multicolumn{6}{|l|}{ Different places of South Gujarat } \\
\hline Jackfruit & Navsari & Karadi & Hasapur & Bardoli & Songadh & Valsad \\
\hline Tamarind & Navsari & Dharampur & Valsad & Pardi & Chikhli & Dang \\
\hline Indian jujube & Navsari & Vyara & Dang & Dungri & Bardoli & Aat \\
\hline Amla & Navsari & Pardi & Karadi & Tapi & Hasapur & Gandevi \\
\hline
\end{tabular}


Table.2 Amount of micro and macro nutrient of Jackfruits collected from different places of South Gujarat

\begin{tabular}{|c|c|c|c|c|c|c|c|c|c|c|}
\hline \multirow[t]{2}{*}{ Location } & \multicolumn{6}{|c|}{ Macronutrient } & \multicolumn{4}{|c|}{ Micronutrient } \\
\hline & $\begin{array}{c}\mathrm{N} \\
\mathrm{mg} / 100 \mathrm{gm}\end{array}$ & $\begin{array}{c}P \\
\mathrm{mg} / 100 \mathrm{gm}\end{array}$ & $\begin{array}{c}\mathrm{K} \\
\mathrm{mg} / 100 \mathrm{gm}\end{array}$ & $\begin{array}{c}\mathrm{Ca} \\
\mathrm{mg} / 100 \mathrm{gm}\end{array}$ & $\begin{array}{c}\mathrm{Mg} \\
\mathrm{mg} / 100 \mathrm{gm}\end{array}$ & $\begin{array}{c}\mathrm{S} \\
\mathrm{mg} / 100 \mathrm{gm}\end{array}$ & $\begin{array}{c}\mathrm{Fe} \\
\mathrm{mg} / 100 \mathrm{gm}\end{array}$ & $\begin{array}{c}\text { Zn } \\
\mathrm{mg} / 100 \mathrm{gm}\end{array}$ & $\begin{array}{c}\text { Mn } \\
\mathrm{mg} / 100 \mathrm{gm}\end{array}$ & $\begin{array}{c}\mathrm{Cu} \\
\mathrm{mg} / 100 \mathrm{gm}\end{array}$ \\
\hline Navsari & 184.53 & 383.70 & 309.33 & 35.10 & 31.90 & 61.00 & 1.70 & 0.11 & 0.50 & 0.78 \\
\hline Karadi & 183.26 & 380.50 & 261.00 & 34.96 & 32.01 & 61.33 & 1.88 & 0.09 & 0.50 & 0.79 \\
\hline Hasapur & 182.43 & 386.97 & 285.33 & 33.81 & 31.92 & 62.00 & 2.04 & 0.10 & 0.55 & 0.8 \\
\hline Bardoli & 184.37 & 409.30 & 314.67 & 36.09 & 32.88 & 63.66 & 1.02 & 0.10 & 0.57 & 0.84 \\
\hline Songadh & 181.40 & 398.87 & 337.00 & 35.07 & 32.35 & 64.33 & 1.42 & 0.10 & 0.52 & 0.81 \\
\hline Valsad & 181.57 & 411.50 & 338.67 & 35.37 & 31.93 & 63.66 & 1.37 & 0.09 & 0.50 & 0.76 \\
\hline Mean & 182.93 & 395.14 & 307.67 & 35.07 & 32.17 & 63.66 & 1.57 & 0.10 & 0.52 & 0.76 \\
\hline CD@ $@ 5 \%$ & NS & 4.741 & 10.683 & 0.278 & NS & NS & 0.142 & NS & NS & NS \\
\hline
\end{tabular}

NS: Non Significant

Table.3 Amount of micro and macro nutrient of Tamarind collected from different places of South Gujarat

\begin{tabular}{|c|c|c|c|c|c|c|c|c|c|c|}
\hline \multirow[t]{2}{*}{ Location } & \multicolumn{6}{|c|}{ Macronutrient } & \multicolumn{4}{|c|}{ Micronutrient } \\
\hline & $\begin{array}{l}\mathrm{N} \\
\mathrm{mg} / 100 \mathrm{gm}\end{array}$ & $\begin{array}{l}P \\
\text { mg/100gm }\end{array}$ & $\begin{array}{l}\mathrm{K} \\
\mathrm{mg} / 100 \mathrm{gm}\end{array}$ & $\begin{array}{l}\mathrm{Ca} \\
\mathrm{mg} / 100 \mathrm{gm}\end{array}$ & $\begin{array}{l}\mathrm{Mg} \\
\mathrm{mg} / 100 \mathrm{gm}\end{array}$ & $\begin{array}{l}\mathrm{S} \\
\mathrm{mg} / 100 \mathrm{gm}\end{array}$ & $\begin{array}{l}\mathrm{Fe} \\
\mathrm{mg} / 100 \mathrm{gm}\end{array}$ & $\begin{array}{l}\mathrm{Zn} \\
\mathrm{mg} / \mathbf{1 0 0 g m}\end{array}$ & $\begin{array}{l}\mathrm{Mn} \\
\mathrm{mg} / 100 \mathrm{~g} \\
\mathrm{~m}\end{array}$ & $\begin{array}{l}\mathrm{Cu} \\
\mathrm{mg} / 100 \mathrm{gm}\end{array}$ \\
\hline Navsari & 82.24 & 6.09 & 34 & 85.00 & 80.67 & 144.66 & 0.96 & 0.12 & 2.80 & 0.103 \\
\hline Dharampur & 72.21 & 6.03 & 32 & 81.67 & 83.00 & 149.66 & 0.89 & 0.10 & 2.17 & 0.1 \\
\hline Valsad & 72.69 & 6.16 & 33 & 84.67 & 82.00 & 143.33 & 0.94 & 0.10 & 2.08 & 0.096 \\
\hline Pardi & 73.84 & 6.18 & 31 & 86.00 & 87.33 & 141.66 & 0.88 & 0.11 & 2.22 & 0.09 \\
\hline Chikhli & 73.90 & 6.03 & 30 & 90.67 & 85.67 & 143.66 & 0.87 & 0.11 & 2.12 & 0.097 \\
\hline Dang & 67.81 & 5.95 & 34 & 78.00 & 87.67 & 145.66 & 0.94 & 0.09 & 2.08 & 0.1 \\
\hline Mean & 73.78 & 6.07 & 32 & 84.33 & 84.39 & 145.66 & 0.91 & 0.11 & 2.25 & 0.1 \\
\hline CD @ 5\% & NS & 0.144 & NS & NS & 3.275 & NS & NS & NS & 0.103 & NS \\
\hline
\end{tabular}

NS: Non Significant

Table.4 Amount of micro and macro nutrient of Ber collected from different places of South Gujarat

\begin{tabular}{|l|c|c|c|c|c|c|c|c|c|c|}
\hline \multirow{2}{*}{ Location } & \multicolumn{9}{|c|}{ Macronutrient } & \multicolumn{4}{c|}{ Micronutrient } \\
\cline { 2 - 11 } & $\begin{array}{c}\mathbf{N} \\
\mathbf{m g / 1 0 0 g m}\end{array}$ & $\begin{array}{c}\mathbf{P} \\
\mathbf{m g} / \mathbf{1 0 0 g m}\end{array}$ & $\begin{array}{c}\mathbf{K} \\
\mathbf{m g} / \mathbf{1 0 0 g m}\end{array}$ & $\begin{array}{c}\mathbf{C a} \\
\mathbf{m g} / \mathbf{1 0 0 g m}\end{array}$ & $\begin{array}{c}\mathbf{M g} \\
\mathbf{m g} / \mathbf{1 0 0 g m}\end{array}$ & $\begin{array}{c}\mathbf{S} \\
\mathbf{m g} / \mathbf{1 0 0 g m}\end{array}$ & $\begin{array}{c}\mathbf{F e} \\
\mathbf{m g} / \mathbf{1 0 0 g m}\end{array}$ & $\begin{array}{c}\mathbf{Z n} \\
\mathbf{m g} / \mathbf{1 0 0 g m}\end{array}$ & $\begin{array}{c}\text { Mn } \\
\mathbf{m g} / \mathbf{1 0 0 g m}\end{array}$ & $\begin{array}{c}\mathbf{C u} \\
\mathbf{m g} / \mathbf{1 0 0 g m}\end{array}$ \\
\hline Navsari & 144.33 & 477.00 & 75.06 & 90.90 & 68.89 & 86.00 & 0.43 & 0.23 & 40 & 0.64 \\
\hline Vyara & 163.33 & 496.00 & 74.54 & 90.92 & 68.67 & 88.23 & 0.45 & 0.26 & 38 & 0.66 \\
\hline Dang & 153.00 & 486.00 & 75.14 & 91.00 & 69.14 & 82.00 & 0.44 & 0.25 & 41 & 0.65 \\
\hline Dungri & 163.33 & 500.00 & 74.85 & 90.96 & 68.87 & 82.10 & 0.43 & 0.25 & 39 & 0.63 \\
\hline Bardoli & 148.00 & 485.00 & 75.01 & 90.94 & 68.85 & 87.00 & 0.46 & 0.27 & 38 & 0.65 \\
\hline Aat & 159.67 & 480.67 & 74.85 & 90.98 & 69.14 & 84.33 & 0.42 & 0.24 & 37 & 0.65 \\
\hline Mean & 155.28 & 487.44 & 74.91 & 90.95 & 68.93 & 84.33 & 0.44 & 0.25 & 39 & 0.65 \\
\hline $\begin{array}{l}\text { CD @ } \\
\text { 5\% }\end{array}$ & $\mathbf{8 . 7 8 6}$ & $\mathbf{1 5 . 2 5 9}$ & $\mathbf{N S}$ & $\mathbf{0 . 1 5 6}$ & $\mathbf{N S}$ & $\mathbf{2 . 9 0 5}$ & $\mathbf{0 . 0 1 5}$ & $\mathbf{0 . 0 2 3}$ & $\mathbf{N S}$ & $\mathbf{N S}$ \\
\hline
\end{tabular}

NS: Non Significant 
Table.5 Amount of micro and macro nutrient of Amla collected from different places of South Gujarat, India

\begin{tabular}{|c|c|c|c|c|c|c|c|c|c|c|}
\hline \multirow[t]{2}{*}{ Location } & \multicolumn{6}{|c|}{ Macronutrient } & \multicolumn{4}{|c|}{ Micronutrient } \\
\hline & $\begin{array}{c}\mathrm{N} \\
\mathrm{mg} / 100 \mathrm{gm}\end{array}$ & $\begin{array}{c}P \\
\mathrm{mg} / 100 \mathrm{gm}\end{array}$ & $\begin{array}{c}\mathrm{K} \\
\mathrm{mg} / 100 \mathrm{gm}\end{array}$ & $\begin{array}{c}\mathrm{Ca} \\
\mathrm{mg} / 100 \mathrm{gm}\end{array}$ & $\begin{array}{c}\text { Mg } \\
\mathrm{mg} / 100 \mathrm{gm}\end{array}$ & $\begin{array}{c}\mathrm{S} \\
\mathrm{mg} / 100 \mathrm{gm}\end{array}$ & $\begin{array}{c}\mathrm{Fe} \\
\mathrm{mg} / 100 \mathrm{gm}\end{array}$ & $\begin{array}{c}\mathrm{Zn} \\
\mathrm{mg} / \mathbf{1 0 0 g m}\end{array}$ & $\begin{array}{c}\text { Mn } \\
\text { mg/100gm }\end{array}$ & $\begin{array}{c}\mathrm{Cu} \\
\mathrm{mg} / 100 \mathrm{gm}\end{array}$ \\
\hline Navsari & 131.20 & 48.33 & 18.96 & 128.26 & 10.80 & 46.33 & 1.24 & 0.34 & 42 & 0.12 \\
\hline Pardi & 143.33 & 47.33 & 19.60 & 127.60 & 10.82 & 45.00 & 1.27 & 0.35 & 43 & 0.14 \\
\hline Karadi & 127.07 & 45.33 & 19.20 & 127.62 & 10.88 & 45.33 & 1.24 & 0.34 & 40 & 0.12 \\
\hline Tapi & 132.17 & 44.33 & 18.54 & 126.91 & 10.96 & 47.33 & 1.23 & 0.32 & 42 & 0.11 \\
\hline Hasapur & 139.07 & 46.00 & 19.91 & 127.54 & 10.77 & 47.00 & 1.23 & 0.34 & 42 & 0.12 \\
\hline Gandevi & 134.40 & 45.67 & 20.02 & 129.20 & 10.70 & 43.00 & 1.24 & 0.36 & 41 & 0.10 \\
\hline Mean & 134.54 & 45.33 & 19.86 & 127.86 & 10.82 & 43 & 1.25 & 0.34 & 42 & 0.12 \\
\hline CD@ $@ 5 \%$ & 5.997 & NS & NS & NS & NS & NS & NS & NS & NS & NS \\
\hline
\end{tabular}

NS: Non Significant

The higher content of phosphorous found in ber fruit grown in Dungri side $(500 \mathrm{mg} /$ $100 \mathrm{gm})$ followed by Vyara (496mg/ 100gm) Bardoli (485mg/ 100gm). The results were comparable with data reported by $\mathrm{Li}$ et al., (2007).

Higher potassium content was observed in Navsari region fruits $(75.06 \mathrm{mg} / 100 \mathrm{gm})$ and lower potassium content was recorded in Vyara fruits $(74.54 \mathrm{mg} / 100 \mathrm{gm})$. Li et al., (2007) accounted $79.2 \mathrm{mg} / 100 \mathrm{gm}$ potassium content in ber fruit form different ber varieties which is agree with above results

Significantly higher content of calcium was found in Dang fruits $(91.00 \mathrm{mg} / 100 \mathrm{gm})$. The calcium content of present work similar with Yazao cultivar of ber91.00 mg/100gm reported by Li et al., (2007).

Higher magnesium content was observed in Navsari region fruits $(68.89 \mathrm{mg} / 100 \mathrm{gm})$. Bakshi and Singh (1974) reported the magnesium content of ber fruits was about $65 \mathrm{mg} / 100 \mathrm{gm}$.

The maximum content of sulfur reported in Vyara fruits $(88.23 \mathrm{mg} / 100 \mathrm{gm})$ which is at par with Bardoli fruits $(87 \mathrm{mg} / 100 \mathrm{gm})$. The sulfur content of ber differ location wise and higher content of sulfur found in Vyara may be due to soil availability.
The higher iron content was reported in Bardoli fruits $(0.46 \mathrm{mg} / 100 \mathrm{gm})$ which is at par with Vyara fruits $(0.45 \mathrm{mg} / 100 \mathrm{gm})$. Morton, (1987); Pareek and Dhaka, (2008) and Pareek et al., (2009) revealed that ber fruit iron content ranged from $0.76 \mathrm{mg} / 100 \mathrm{gm}$ to 1.8 $\mathrm{mg} / 100 \mathrm{gm}$ which are comparable with present work. The iron content in Ber slightly differ may be due to technical error in analysis.

The ber fruit for present study were collected from six different location of South Gujarat. The results showed the highest zinc content in fruits collected from Bardoli $(0.27 \mathrm{mg}$ /100gm). Li et al., (2007) revealed that Ber fruit zinc content contains ranges from $0.35 \mathrm{mg} / 100 \mathrm{gm}$ to $0.63 \mathrm{mg} / 100 \mathrm{gm}$.

Numerically higher value of manganese content was found in place Dang $41 \mathrm{mg} / 100 \mathrm{gm}$ and that of lower in Aat $37 \mathrm{mg} / 100 \mathrm{gm}$. These results are similar to the finding of Li et al., (2007) and Wafaa et al., (2011). They reported that Ber fruit manganese content ranged from 24.6 to 51.2 $\mathrm{mg} / 100 \mathrm{gm}$.

The maximum value was found under place Dang $0.41 \mathrm{mg} / 100 \mathrm{gm}$. These results are similar to the finding of Li et al., (2007) and Wafaa et al., (2011). They found that $\mathrm{Cu}$ content in ber fruit ranged from 24.6 to $51.2 \mathrm{mg} / 100 \mathrm{gm}$. 


\section{Mineral elements of amla}

The data concerned mineral elements of the Amla fruit taken from different sites of South Gujarat had been presented in table 5. Amla fruit juice had the higher content of nitrogen content found grown in Pardi side (143.33mg/ $100 \mathrm{gm})$ followed by Hasapur fruits $(139.07 \mathrm{mg} / 100 \mathrm{gm})$. This result is similar to finding of Gopalan et al., (1991).

They obtained nitrogen content of amla varied from 124 to $185 \mathrm{mg} / 100 \mathrm{gm}$. it might be due to the variation in environmental conditions and soil type.

The maximum value of phosphorous content was reported in Navsari fruits $(48.33 \mathrm{mg} / 100 \mathrm{gm})$. The results of above finding agree with following study. According to Parveen and Khatkar in 2015 phosphorous content in different cultivars of Amla varied from 45 to $65 \mathrm{mg} / 100 \mathrm{gm}$.

The maximum value of potassium content was reported in Gandevi side fruits $(20.02 \mathrm{mg} / 100 \mathrm{gm})$. The result of present study was agreed with Barthakur and Arnold (1991). They reported that potassium content ranged from 20 to $25 \mathrm{mg} / 100 \mathrm{gm}$.

Highest calcium content was recorded in Gandevi location fruits $(129.20 \mathrm{mg} / 100 \mathrm{gm})$. Similar results of calcium have been reported by Gopalan et al., (1991). They observed ranged of calcium content varied from 120 to $200 \mathrm{mg} / 100 \mathrm{gm}$ respectively.

Highest magnesium content was recorded in Tapi location fruits $(10.96 \mathrm{mg} / 100 \mathrm{gm})$. The results were comparable with data reported by Gopalan et al., (1991). They reported that magnesium content varied from 7.55 to 12.50 $\mathrm{mg} / 100 \mathrm{gm}$ respectively.

Sulfur content in amla fruits ranged from 43 to $47.33 \mathrm{mg} / 100 \mathrm{gm}$. The highest sulfur content was observed in Tapi fruits $(47.33 \mathrm{mg} / 100 \mathrm{gm})$ followed by Hasapur fruits $47.00 \mathrm{mg} / 100 \mathrm{gm}$. The range of sulfur content in Amla varied from (0.07 to $0.13 \mathrm{mg} / 100 \mathrm{gm})$ reported by Ragone, and Cavaletto (2006) respectively. The maximum value of iron content was obtained in Pardi fruits $(1.27 \mathrm{mg} / 100 \mathrm{gm})$. The value of iron is comparable with results of Gopalan et al., (1991). They found iron content in amla fruits was about $1.2 \mathrm{mg} / 100 \mathrm{gm}$.

The maximum value of $\mathrm{Zn}$ content recorded in Gandevi location fruits $(0.36 \mathrm{mg} / 100 \mathrm{gm})$. The zinc content in amla varieties varied from 45 to $53 \mathrm{mg} / 100 \mathrm{gm}$ which is higher than present results due to different genotypes and environmental conditions reported by Parveen and Khatkar in 2015.

Higher content was observed in Pardi grown fruits $(43 \mathrm{mg} / 100 \mathrm{gm})$. The range of manganese content in varied from $40 \mathrm{mg}$ $/ 100 \mathrm{gm}$ to $43 \mathrm{mg} / 100 \mathrm{gm}$.

The present finding was in very close with the findings of Poonam and Mahanta (2014). They reported that manganese content in amla fruit was about $50 \mathrm{mg} / 100 \mathrm{gm}$.

Higher copper content was observed in Pardi grown fruits $(0.14 \mathrm{mg} / 100 \mathrm{gm})$ while, the lowest values of copper content in 0.10 $\mathrm{mg} / 100 \mathrm{gm}$ Gandevi fruits respectively.

\section{Acknowledgments}

The author is thankful to the Department of Soil Science and Agricultural Chemistry, N. M. College of Agricultural, Navsari Agricultural University, Navsari, for allowing me to mineral analysis by atomic absorption spectrophotometer. Sincere thanks and obligations are also extended to Dr. Nilima Karmarkar and Dr. Sonal Tripathi, for her valuable advice suggestions encouraged me throughout this work. 


\section{References}

Bharthakur, N. N., and Arnold, N. P. 1991. Chemical analysis of the emblic (Phyllanthus emblica L.) and its potential as a good sources. Sci. Horti. 47: 99-105.

Coronel, R. E., 1991. Tamarindus indica L. In Plant Resources of South East Asia, Wageningen; Pudoc. No. 2. Edible Fruits and Nuts. (Eds). E.W.M. Verheij and R.E. Coronel, PROSEA Foundation, Bogor, Indonesia: 298 301. Delhi.

Elwell, W.T., and Gridley, J. A. F. 1967. Atomic absorption spectro photometery pergamon press Ltd., London, and W-1.

Gopalan, C., Sastri, B.V.R., Balasubramaniam, S.C. 1991. Nutritive value of Indian foods.NIN, Hyderabad, India, His Majestyes Government of Nepal, Ministry of Forest and Soil Conservation, Department of Medicinal Plants. Medicinal Plants of Nepal (3rd Ed). His Majestye's Government Press, Kathmandu: 185.

Goswami, C., Hossain, M. A., Kader, H. A. and Islam, R. 2011. Assessment of Physicochemical Properties of Jackfruitse (Artocarpus heterophyllus $^{\text {ee }}$ Lam) Pulps. J. Horti. Forestry \& Biotec., 15(3): 26- 31.

Gunasena Gunasena, H.P.M., Ariyadasa, K.P., Wikramasinghe, A., Herath, H.M.W., Wikramasinghe, P. and Rajasearuna, S.B. 1996. Manual of Jack cultivation in Sri Lanka. Forestry Information Service. Forest Department: 48.

Hegde, N.G. 2009. Promotion of Underutilised Crops for Income Generation and Environmental Sustainability. Proc. of the International Symposium on "Underutilised Plants for Food Security, Nutrition, Income and Sustainability Development",
Arusha, Tanzania. Organised by the International Centre for Under-utilised Crops (ICUC), Colombo. March 3-7. Acta Horticulturae, No. 806. 2: 563-569 Jackson, M.L., 1967. Soil Chemical Analysis, Prentice Hall of India Private Limited, New Delhi: 111-203.

Jackson, M.L., 1979. Soil chemical analysis. Prentice hall of India Private Limited, New Delhi. pp: 205.

Jain, S.K., and Akhurdiya, D.S. 2000. Anola: Potential fruit for processing Delhi Garden Mega; 38:50-51.

Khatoon, S., Rai, V., Rawat, A.K.S., Mehrotra, S., 2006. Comparative pharmacognostic studies of three Phyllanthus species. Ethnopharmaco., 104: 79-86.

Leonard, J., 1957. Genera des Cynometreaeet des Amherstieaeafricaines (Leguminosae- Caesalpinioideae). Mémoire Acad. Royale Belgique, 30(2): 1-314.

Li, J. W., Fan, L.P., Ding, S.D. and Ding SL 2007. Nutritional composition of five cultivars of Chinese jujube. Food Chem. 103: 454-460.

Mazumdar, B. C., 2004, Minor Fruit Crops in India, Daya Publishing House, New

Morton, J., 1987. Indian Jujube. Http://www.hort.Purdue.edu/newcrop/ morton/indian_jujube.

Narashimham, P., 1990. Breadfruit and jackfruit. In: Nagy S, Shaw PE, Wardowski WF. (Eds.). Fruits of Tropical and Subtropical Origin Composition, Properties and Uses. Florida: Florida Science Source, Inc. p. 216-259.

Pareek, S., L. Kitinoja, R. A. Kaushik and R. Paliwal.2009. Postharvest physiology and storage of ber. Stew. Posthar. Rev. 5(5):1-10.

Parveen, K., and Khatkar, B.S. 2015. Physicochemical properties and nutritional composition of aonla (Emblica officinalis) varieties. Int. Food Resea. 
J., 22(6): 2358-2363.

Parvez, S.S., Parvez, M.M., Nishihara, E., Gemma, H. and Fujii, Y. 2003. Tamarindus indica L. leaf is a source of allelopathic substance. Plant Growth Regulation, 40 (2)107-115.

Poonam, M., and Mahanta C. L. 2014.Comparative Analysis of Functional and Nutritive Values of Amla (Emblica officinalis) Fruit, Seed and Seed Coat Powder. American Journal of Food Technology, 9: 151161.

Priya, S.D., Talaulikar, S. M., Gupta, J., Thangam, M. and Singh, N. P. 2014. A Guide on Cultivation and Value Addition Technical Bulletin No.: 41.

Ragone, D., and C.G. Cavaletto.2006. Sensory evaluation of fruit quality and nutritional composition of 20 breadfruit (Artocarpus, Moraceae) cultivars. Econ. Bot., 60(4): 335- 346.

Scartezzini, P., and Speroni, E. 2000. Review on some plants of Indian traditional medicine with antioxidant activity. $J$. Ethnopharmaco., 71: 23-43.

Tandon, H. L. S., 1993. Methods for analysis of soils, plant, water and fertilizers. Fertilizers Development and Consultation Organization, New Delhi, India.

Tiwari, A.K., and Vidyarthi, A. S. 2015. Nutritional Evaluation of Various Edible Fruit Parts of Jackfruit (Artocarpus heterophyllus) at Different Maturity Stages. Int. J. Chem. Pharm. Rev. Res. 1 (2): 21-26.

Wafaa, M., Abozeid, I.M.F., Helmy, Nadir, A. and Esmat, A. Abou- Arab (2011).Production and Development of New Products from Local and Chinese Ber Fruits. Aust. J. Basic \& Appl. Sci., 5(6): 652-659.

Wenkam, N.S., and Miller, C.D. 1965. Composition of Hawaii Fruits. Hawaii Agriculture Experimental Station, University of Hawaii, Bulletin, 135:1965.

\section{How to cite this article:}

Abuj Bhagyashree, B., Nilima Karmakar, V. Rathwa Kalpana, Kapadiya Chintan and Narwade Ajay, V. 2017. Mineral Content of Minor Fruits of South Gujarat. Int.J.Curr.Microbiol.App.Sci. 6(9): 680-689. doi: https://doi.org/10.20546/ijcmas.2017.609.083 